\title{
Truth, Reason, and Faith in Modern Civilisation: The violence of truth and the truth of violence in modern 'secular' Western civilisation
}

Author:

Johann-Albrecht Meylahn

Affiliation:

${ }^{1}$ Department of Practical Theology, University of

Pretoria, South Africa

Correspondence to: Johann-Albrecht Meylahn

Email:

jmeylahn@lantic.net

Postal address:

Private Bag X20, Hatfield,

Pretoria 0028, South Africa

Dates:

Received: 24 Jan. 2012

Accepted: 04 May 2012

Published: 09 July 2012

How to cite this article: Meylahn, J-A., 2012, 'Truth, Reason, and Faith in Modern Civilisation: The violence of truth and the truth of violence in modern 'secular' Western civilisation', Verbum et Ecclesia 33(1), Art. \#712, 8 pages. $\mathrm{http}: / / \mathrm{dx}$.doi. org/10.4102/ve.v33i1.712

C 2012. The Authors. Licensee: AOSIS OpenJournals. This work is licensed under the Creative Commons Attribution License.
What is truth? What is reason? What is faith? These questions have been hotly debated and have been the cause of violence prior to the rise of the modern and so-called secular state. The rise of the modern 'secular' state was founded on the distinction between reason and faith thus bringing to an end the religious violence which was inspired by their respective truths. The concept of truth will be questioned, thus questioning the 'truth' that reason and faith can be neatly separated from each other and consequently that the secular and religious can be separated into neat categories. There is an inherent violence (political, religious and linguistic) in the Truth(s), be it the truths of either religion or secular reason, namely the originary linguistic violence of truth. This article will ask the question: How can one speak of truth, reason and faith in a modern civilisation and seek ways beyond the violence of truths towards interdisciplinary open dialogue of a democracy still to come?

\section{Introduction}

The theme of the ACERP 2011 conference $^{1}$ relates truth, reason, faith and modern civilisation to one another, and it is this relation between them that has shaped much of modern Western history. The thoughts offered here are mainly from a Western and, more specifically, from a continental philosophical perspective.

The search for truth based on either reason or faith has certainly shaped the rise of modern Western civilisation. Firstly it was the truths of faith that determined the history of Europe from the time that the Roman Empire became Christian through the time of the Holy Roman Empire and the rise of various independent kingdoms of Western Europe in the time of the Reformation. These truths of faith shaped and formed the borders of Christian civilisation. In the name of religious truth, wars were declared, inquisitions ordered, witch hunts executed and crusades undertaken into foreign lands, all in the name of truth and against the so-called 'enemies of truth'.

At the time of the Reformation, a new form of civilisation was emerging as individual states sought autonomy from the Holy Roman Empire. For these states (kingdoms), the new truths of the Reformation provided the necessary foundation and legitimisation to liberate themselves from the 'old' truths of the Roman Catholic Church and thereby establish autonomous states founded on their own truth. In this context where political violence needed to be legitimised, the truths of faith played a central role ${ }^{2}$ and thus the so-called religious wars started in Europe. In these wars, various truths of faith were posed against each other as the ideological justification for the establishment of autonomous kingdoms or in defence of the Holy Roman Empire.

These wars were brought to an end by a new truth that justified and legitimised the birth of the modern 'secular' state [state founding violence] (cf. Benjamin 1996; Meylahn 2011), namely what became known as the objective truth of secular reason.

It is clear that in the history of modern Europe, truth, faith, reason and modern civilisation cannot be separated from each other, but together they weave the tapestry of this civilisation. This is a tapestry stained with the blood of violence - violence in the name of truth: the violence of truth.

For a long time in modernity, it was believed that this is not a tapestry woven together from various strands, but a solid foundation and the belief that humanity had arrived at the eschaton of history. Human scientific reason had won the victory over the contingencies of myth, fate, nature and the competing truths of institutionalised faith (religion). This universal absolute truth of

1.The theme of the Asian Conference on Ethics, Religion and Philosophy in Osaka, Japan from 20-22 March was Truth, Reason, and Faith in Modern Civilisation.

2.For further development of the rise of the European nation states, see Cavanaugh (1995) and Meylahn (2011). 
human scientific reason translated into the desire to construct perfect modern civilisations which were liberated from the myths of faith. This desire to construct a perfect society based on a universal truth easily translated into various forms of modern totalitarian dictatorships (cf. Todorov 2001).

This solid foundation crumbled as history revealed the human atrocities of these totalitarian systems. However, the crumbling had already begun when the solid foundation of reason was questioned by thinkers such as Nietzsche and Heidegger on the continent and Wittgenstein in the United Kingdom (UK). The clear and absolute distinction between truth based on reason and truth based on faith was questioned (cf. Meylahn 2011). This questioning of absolute universal truth would have consequences with regards to the interpretation of modern and postmodern civilisations.

\section{The Violence of Truth}

Truth as subject is central to the philosophical tradition and has been the topic of discussion for thousands of years. In the contemporary philosophical debate, there are three main lines of thought with regards to truth, namely truth as correspondence, truth as coherence and pragmatist theories of truth. Within the context of the theme, the focus will not be on the various arguments of these three theories of truth, but on the relationship between reason, faith and civilisation. Thus the question is not purely how truth is to be understood, but how it relates to reason, faith and civilisation.

Heidegger argued that correspondence is certainly the way truth is commonly understood, although he uses slightly different terms. Heidegger, in his reflection on the essence of truth, refers to the usual concept of truth. According to him, the usual concept of truth, which is necessary for the functioning of society, is based on accord [Übereinstimmung], which refers to both that which is actual and that which is genuine (Heidegger 2005:244). Nietzsche argues that this usual sense of truth as correspondence is not only how truth is understood, but is also a necessity for the good functioning of society (Nietzsche 2005), and thus truth as correspondence or coherence is necessary for the maintenance of civilised order - civilisation.

These ideas of truth as correspondence refer to the traditional definition of truth as veritas est adaequatio rei et intellectus: truth is the correspondence [Angleichung] of matter to knowledge. However as Heidegger argues, this can also mean truth is the correspondence of knowledge to matter (Heidegger 2005:245). He argues that these two versions are not just inversions, but that in each case intellectus and res are thought differently. He argues that this interpretation does not only lead back to Kant's idea that objects conform to our knowledge, but it rather extends further back to the Christian theological belief that res as created matter corresponds to an idea preconceived in the intellectus divinus (mind of God) (Heidegger 2005:245). Thus there is a clear link between truth, reason and faith. The question is: Has the link to faith ever been severed, as was believed in the rise of secular reason?
Heidegger argues that, irrespective of truth referring to the correspondence between intellectus divinus and matter (beings) or not, truth is always understood within the context of some or other world-order (world-view), such as intellectus divinus or later Weltvernunft [universal reason]. It is clear from this that truth as correspondence is always embedded within a larger metaphysical or epistemological system of thought, and it cannot be understood apart from this system. Yet the dependence of the theories of truth on this system is often not thought, or it is forgotten.

This system or world-order, be it metaphysical or epistemological, within which truth is understood and which in turn is based on the understanding of truth is at heart mythological, as Nietzsche argues that one believes one knows something about the things themselves when one speaks of trees, colours, snow and flowers, and yet one possesses nothing but metaphors for things (Nietzsche 2005:16). Derrida would later take up this theme from Nietzsche and Heidegger in his article White Mythology where he argues that the relationship between thought, language and reality, in which truth as correspondence is interpreted, is based on metaphors (cf. Derrida 1974:5) and that we cannot move beyond metaphors.

\section{Derrida (1974) argues that metaphysics is:}

a white mythology which assembles and reflects Western culture: the white man takes his own mythology (that is, IndoEuropean mythology), his logos - that is, the mythos of his idiom, for the universal form of that which is still his inescapable desire to call Reason. (p. 11)

Western secular civilisation, which was believed to be beyond myth and founded on objective scientific truth, is in 'truth' mythological. In other words, even a so-called scientific world-view is founded on a metaphor.

Metaphor has always been defined as a trope of resemblance; not simply between signifier and signified, but between what are already two signs, the one designating the other (Derrida 1974:13).

Truth, understood as correspondence, is based on the idea that a statement corresponds to something else, for example, to a thing in reality or to correspondence between two signs. So the basis of truth as correspondence is that two dissimilar things are brought into approximation with each other where the one resembles the other, which is the classic description of metaphor. For example, a statement says something about a thing in such a manner that the thing is presented - is made present in its absence, which is possible through metaphor. Aristotle argues in Poetics that to produce a good metaphor is to see a likeness and thus what makes a good metaphor possible is also what makes truth possible (Derrida 1974:37). It is for this reason that Heidegger speaks of poetry as the purest form of language (Heidegger 1971).

Through metaphor, the thing (object) becomes present and this means that metaphor allows the thing, for example a coin, to stand out as an object. It can only stand out as an object, 
'coin', within a world of money that gives meaning to the object as a coin. It can stand out as an object (stand opposed as object) only by traversing an open field of opposedness and nevertheless must maintain its stand as a thing and show itself as something withstanding (Heidegger 2005:247). This open field in which the presenting takes place is not only created by the presenting but is rather only entered into and taken over as a domain of relatedness. This is a relatedness between standing out (beings) in the open field and what is opened up as such (Being). The coin stands out as coin only in the context of money. In Identity and Difference, Heidegger places these thoughts into the language of beings and Being. Thus one can argue that beings (that which stands out, i.e. things) only appear in and through the coming-over of Being (Heidegger 1969:65). One can express this in two ways:

1. The coming-over [Überkommnis] of Being into beings is at the same time the coming on [an-kommen] the scene of beings.

2. The beings appear on the scene only in the coming-over of Being.

This means that although the coming-over of Being in beings is the unconcealment (arrival, appearing or presencing) of beings, it is also the concealment (withdrawal) of Being. The coin only stands out as coin in the coming over of money or in that the coin finds its place within the world of money. Yet humans forget that the coin only has meaning within the system of money and believe that the coin is actual and genuine independent of the system that gives it meaning. This is what Heidegger refers to as Seinsvergessenheit [the oblivion of Being].

When he speaks of Seinsvergessenheit, Heidegger does not mean that metaphysics does not think Being because all metaphysics thinks Being, and it thinks Being in terms of presencing. What he is refering to is an oblivion of the difference which makes the difference between Being and beings possible, the dif-ference which makes the ontological difference possible and thus offers to metaphysics its subject matter.

It is in this context that Heidegger will later understand the role of language and how humanity is implicated in the ontological difference, in other words how we are implicated in the grammar of metaphysics where the dif-ference remains unthought or beyond grammar.

For Heidegger, it is language that opens up the metaphysical difference and thus humanity is implicated in that difference through language or through difference in language. That means that the dif-fering in the difference which belongs to all metaphysics is an essentially linguistic event (Caputo 1982:158). It is not only the Being of beings that is a linguistic event, but humanity as humanity is a linguistic event. Language calls into the realm of the absent summoning into presence. Thus he argues that language does not represent things, but rather lets them be in their Being as it is not representative, but manifestative. What does language summon to presence? It summons both 'thing' and 'world'. Each 'thing' is summoned to presence as what it is [apophainesthai] within the constellation of the 'fourfold' [Geviert], which is the world.

Language, through naming various things, creates a world in which these things find a home. He says: 'by thinging, things carry out world' (Heidegger 1971:200). There is a very close relationship between the things called into nearness and the place of arrival (world into which they are called). The world grants things their presence, but things bear (carry, gebären, give birth ) to the world and this happens within language the house of being.

Thus one can argue that truth as correspondence is dependent on language, as the truth of a statement is not dependent on an external reality, but on the internal logic of language, the metaphorical logic of language - it is dependent on the internal coherence within language.

As Nietzsche would argue, humanity defines the world of mammals and then identifies the camel as a mammal (Nietzsche 2005:17-19). In Heidegger's terms the genus mammal would be the Being and the particular camel would be a being. This being, camel, is then understood, classified and named a mammal, but in the process the ontological difference is forgotten or, as Nietzsche would say, the metaphor is forgotten.

\section{This leads Nietzsche (2005) to his famous statement:}

What then is truth? A movable host of metaphors, metonymies, and anthropomorphisms: in short, a sum of human relations which have been poetically and rhetorically intensified, transferred, and embellished, and which, after long usage, seem to a people to be fixed, canonical, and binding. Truths are illusions which we have forgotten are illusions; they are metaphors that have become worn out and have been drained of sensuous force, coins which have lost their embossing and are now considered as metal and no longer as coins. (p. 17)

Or as Žižek argues, 'Myth is thus the Real of logos: the foreign intruder, impossible to get rid of, impossible to remain fully within' (Žižek 2001). The difficulty is that this reflection on truth is circular. As one is trying to get a grip on something that one is part of, there is no outside perspective on metaphor as one is always in metaphor or the metaphor of metaphor (cf. Derrida 1974:56-60).

One cannot escape being in metaphor, and thus it is human (Nietzsche 2005:21) to be in metaphor. Therefore there is no absolute correspondence but at best coherence in human utterances. From this follows the move towards understanding truth as coherence rather than correspondence and then also the move towards pragmatist theories of truth. Truth as coherence argues that something is true if there is internal coherence between the belief and the other beliefs of a system. In other words, something is true if it fits into the conventional use of the forgotten yet founding metaphor. Similar arguments can be used with regards to the pragmatist theory of truth. In a civilisation that has forgotten its founding myth and where the founding myth 
has been turned into what is natural, certain truths will prove themselves through everyday use and praxis.

The clear line between truth based on reason and faith has been fundamentally questioned with the metaphorical foundation of all language, even so-called universal scientific language. Thus truth, knowledge and reason are to a certain extent all founded on faith in their respective founding metaphors. Or as Derrida says: 'The sign and divinity have the same place and time of birth. The age of the sign is essentially theological' (Derrida 1997:14). Truth as correspondence is based on faith alone. There are certain reasoning strategies with regards to truth as coherence, but even these strategies are based on faith in their founding metaphors. Truth is a matter of choice between different metaphors based on various practical reasons or on various systems of coherence, yet such a choice is always at the exclusion of other possibilities, and thus it is related to power and by implication to violence, also the violence of authority and legitimisation (cf. Benjamin 1996).

\section{Truth and civilisation in the development of modern civilisation towards global capitalism}

States or civilisations are founded on some or other truth that has forgotten its metaphorical origin. Both the foundation of truth and what Nietzsche described as truth drive, the practical necessity of truth, are integral to the functioning of civilisation. The question that comes to mind is: What kind of truth is indispensible (foundation) to our present global capitalist civilisation? The modern state arose on the foundation of the truth of secular universal reason, the truth of positive science, ${ }^{3}$ and these could easily be translated into dreams of utopia (a perfect society). ${ }^{4}$ This in effect became various forms of totalitarian regimes, ${ }^{5}$ and in opposition to these totalitarian regimes is posed liberal democracy (cf. Todorov 2001:40). On what truth is liberal democracy founded? Democracy is certainly an idea that seeks to create room for a plurality of ideas and truths, yet liberal democracy is equally founded on an open and 'free' economic system that is often portrayed as natural - the hidden hand or natural law of the market, if left to itself. In other words, the truth of

3.'Scientism takes as its point of departure a hypothesis about the structure of the world - that it is entirely coherent. Thus, as though the world were transparent, it can be known by human reason without lacunae. This task of knowing is entrusted to be known by human reason without lacunae. This task of knowing is entrusted to an appropriate praxis called science. No part of the world - material, spiritual, aninate, or inanima prexise, an exercise in understanding the world, give rise to technique, an exercise in transforming it'
(Todorov 2001:30).

4.....utopianism consists of the desire to build a perfect society through the efforts of man alone, without any reference to God....Utopianism takes its name from utopia which is nothing more than an intellectual construct, an image of the ideal society.... Utopianism is of necessity tied to coercion and violence...' (Todorov 2001:29).

5.'The notion that science produces the ideals of society and the individual along with other types of knowledge carries important consequences. If ultimate ends were merely an effect of individual choice then each person would have to allow that their choice might not coincide with their neighbour's; as a consequence it would become necessary to accommodate other interests, to practice tolerance and to look for compromises. Several conceptions of the good would coexist. But the same does not apply to the findings of science. Here the false version is mercilessly dismissed and nobody thinks to ask for a little more tolerance on behalf of the refuted hypotheses. Since there is no room for several conceptions of the truth, an appeal to pluralism is out of the question: only errors are many, truth is one. If the ideal is the outcome of a demonstration, and not an opinion, then it must be accepted without dispute' (Todorov 2001:31). liberal democracy is embedded within the metaphysics of global capitalism, which is portrayed as a given (natural) thus a forgotten metaphor (construction).

Even the plurality of truths, which is a fundamental truth of democratic civilisation, is a truth that needs to be interpreted within the context (world) ${ }^{6}$, which in turn is its own construction, and thus as Derrida (1974) argues, we move from one metaphor to another always interpreting one metaphor with the use of another. Yet that is exactly what is needed to allow the different metaphors to deconstruct each other and thereby to create space for the event of a democracy still to come.

One can use Lacan's discourse theory to help interpret the one metaphor in the context of another, namely the 'truth' of liberal democratic civilisation within the 'truth' of the global capitalist world order, the forgotten construction of global capitalist society. It is not a natural given, but as Nietzsche would say, it is an illusion that through repeated use has become natural (cf. Nietzsche 2005:17).

Lacan's discourse theory is based on the theory of language and communication and on the notion that communication, in the context of the above, is always a failure (Lacan 2006; Verhaeghe 1995) because there is an unbridgeable gap between language and reality. This gap is bridged only metaphorically. However, this metaphoric bridge never leads to 'reality' but only to other metaphors ad infinitum.

In this context of communication, there is an agent who desires to say something (communicate something) to someone else with a desired effect (product). This communication sequence is motivated by a truth - a desire to share a certain truth. This desire to share a truth translates into different discourses, and each discourse delineates fundamental relationships, resulting in a particular social bond (Verhaeghe 1995:95). Therefore one can argue that these truth discourses result in particular forms of social interaction that make up civilisation.

Lacan refers back to Freud, who argued that it is truth that drives the speaking subject, so much so that one can say that it is not the ego that speaks but truth that speaks (Verhaeghe 1999:96). This reminds one of Heidegger who said that language speaks. 'In its essence, language is neither expression nor an activity of man. Language speaks' (Heidegger 1971:197). It is the truth of Being that comes to language and that speaks in language. Yet this is exactly the problem, that truth does not come to language completely as the truth of Being, as aletheia, is always disclosedness as well as concealment, or as Lacan would argue, it is a halfspeaking truth. There remains a lack between the 'truth' and the signifier communicating the 'truth' (Meylahn 2010:2 of 9). This half-speaking truth (truth) that speaks through the language of the agent (subject) in an attempt to communicate something to another (other) with a desired effect (product) fails, and thus communication continues ad infinitum. However at the same time, this discourse creates a social bond 6.See Žižek 1997. 
that binds society as part of a specific kind of civilisation. It is beyond the scope of this article to investigate all the Lacanian types of discourses, and thus the focus will only be on the discourse of the hysteric but within the capitalist discourse which Lacan developed only later (cf. Meylahn 2010:3 of 9).

\section{The Capitalist discourse}

The truth of the capitalist discourse is the market, and the agent of this truth is the agent who produces through the other of knowledge and technology, products for consumption. These products of consumption feed the market, and thus the market produces its own self-sustaining truth. Therefore it can be interpreted as a dominant discourse (cf. Meylahn 2010: 3 of 9). Yet humans would revolt against such a discourse that reduces humans to mere mechanical agents of the market. In order to sustain this discourse, the market needs to create a discourse of social bond that convinces the subject of their own subjectivity and that they are not just agents or cogs in the machine of the market. The subject needs to be convinced that they are free from the market mechanisms and that the market is what creates the necessary space for this freedom - the basis of liberal capitalist democracy - free individuals and free market.

Thus it must be the market that offers the individual their freedom, and it does this by offering choice. The possibility to choose from the variety of consumer goods offers the individual the feeling of being a free subject who chooses their individuality through the products of consumption. This feeling of freedom through choice is exactly what the market needs to continue production (cf. Meylahn 2010:3 of 9). Production of objects of consumption feeds the market with its own truth and creates the illusion of freedom and individuality.

\section{The discourse of the hysteric in the context of the capitalist discourse}

As was mentioned above, the only way the capitalist discourse can sustain itself is if the 'truth' of the discourse - the market - is covered up ideologically and replaced with the objects of desire, which are the objects of production (Meylahn 2010:3 of 9). These objects of production become the objects of desire in that they become the truth of the individual: 'I am what I consume!' The truth of the individual then becomes the objects of consumption: I am what I have (Fromm 1976). The subject is no longer a slave to the market as the market's agent in production, but the subject is enslaved to the objects of desire (libidinal enjoyment) (Lacan 2001:415).

The object of truth (object of libidinal enjoyment) is a halfspeaking truth and can never provide the subject with what he or she desires, namely jouissance [left untranslated in the works of Lacan], and thus new objects continually need to be found. The objects of libidinal enjoyment lose their 'truth' the moment they proliferate. Once everybody has this specific object, it can no longer offer the subject their truth as it would be the truth of too many. The subject thus continually has to find new objects, thereby furthering the production of objects which is the truth that sustains the capitalist market.
Žižek (2006a) refers to this as the explosion of the hysterical capitalist subjectivity that has to reproduce itself through permanent self-revolutionising through the integration of the excess into the 'normal' functioning of the social bond. Wajcman (2003) describes the discourse of the hysteric as the fundamental primary discourse as it discloses the structure of speech in general and sheds light on the dimensions of human discursive practice. ${ }^{7}$

In the hysteric's discourse, the other is constituted as capital Other, as the hysteric commands the Other: 'Tell me who I am!' The hysteric demands from the Other, and this demand compels speech as if all language carried this question: Who am I? (Wajcman 2003). This question arises from the structure of language itself, from the subject's symbolic dependence upon the Other and from the fact that all speech proceeds from the place of the Other. It is from the position of the Other that the yet inarticulate subject comes into being through the answer: I am who You say I am! 'In the hysteric's discourse it is as if the subject (S) commanded the Other, yet symbolically, the hysteric is entirely dependent on the 'Other' for being the master signifier that transforms it into a subject' (Meylahn 2010:4 of 9). In this interchange, language is born but with an essential flaw. As the Other answers, the subject comes into being. The answer needs to be necessarily specific and thus reduces the subject to an object, but this finite objectification is never satisfactory, thus the continuous play of language with the infinite différance between signifier and signified (Derrida 1997). This is the reason why the hysteric's discourse is described as the real. The self is a debarred subject as a result of what was mentioned above: the metaphoricalness of language and truth. Yet it is also this discourse that feeds capitalism, as discussed above, because of the role given to the Other. Thus between the hysteric's discourse and the capitalist discourse, there is an ideal fit, and the two complement each other. Is there a way beyond these illusions?

\section{Is there a truth beyond language (metaphor)?}

Derrida argues that, in language, there is an arche-violence ${ }^{8}$ that is tied to the very possibility of language itself (Derrida 1978:125), the violence of a choice based on some or other conception of what is true or believed to be truer. One can thus say that there is an arche-violence in metaphor and thus in truth. Žižek (2008) ${ }^{9}$, agreeing with Derrida, proposes that

7 . Normal hysteria has no symptoms and is an essential characteristic of the speaking subject. Rather than a particular speech relation, the discourse of the hysteric exhibits the most elementary mode of speech. Drastically put: the speaking subject is hysterical as such' (Wajcman 2003).

8. Arche-violence, the primordial violence, appears with every articulation (Derrida 1978:148) as in every articulation there is choice, classification and thus also exclusion of that which does not fit, which is different. In other words, speech without choice, classification, differentiation would not be speech because it would say nothing.

9.'This is why language itself, the very medium of non-violence, of mutual recognition, involves unconditional violence' (Žižek 2008:2).

Žižek (2008) refers to Heidegger's interpretation of the essence of language not as the core truth of language, but the essencing ability of language and he says:

A fundamental violence exists in this 'essencing' of language: our world is given a partial twist, it loses its balanced innocence, one partial colour gives the tone of the whole. (p. 3) 
we need to be aware of this violence and to think this violence. With Hegel, Žižek argues that we need to think language against language, and this reminds one of Walter Benjamin's two forms of violence (mythic and divine) with regards to the founding and preservation of the law (cf. Benjamin 1996). The violence of language which Derrida and Heidegger refer to is mythic violence (sprach-bildende Gewalt) with the force of myth as the primordial narrativisation and/or symbolisation, or to put it into Badiou's terms, the violent imposition of the transcendental coordinates of a World onto the multiplicity of Being. This sprach-bildende Gewalt can be compared to the lawfounding violence that is based on a specific understanding of truth that has forgotten its metaphorical base. This truth is the necessary myth, primordial symbolisation, with which to justify the law-founding or law-maintaining violence against what is different in the creation of a particular civilisation.

One needs to be aware of this violence of language, but there is another form of violence, namely language destroying violence [sprach-zerstörende Gewalt]. Žižek (2008:9), reflecting on the thoughts of Lacan, argues that there is also the violence of thinking (and of poetry), and this can be compared to Benjamin's divine violence as sprach-zerstörende Gewalt. Žižek argues that one needs to focus on (think) the destroying twisting of language in order to enable a trans-symbolic real of a Truth to transpire in it. This can be compared to Lacan's discourse of the analyst. The desire of the analyst in the discourse of the analyst is the desire to establish and keep the opposition between demand and desire. According to Meylahn (2010):

Demand is desire that exists under the illusion that desire can be fulfilled. Pure desire is conscious that the object of desire can never be fulfilled; it becomes desire for pure difference (page 6 of 9).

The desire of pure difference is the knowledge of the structural inability and impossibility of language, namely différance. Thus truth is the desire for the knowledge of différance and no longer the illusion of truth as perfect correspondence.

So, yes, there is a truth beyond language and thus beyond violence - the truth of différance which speaks in the language of pure mathematics, of poetry. But is this still truth?

Derrida would probably call it by another name, but what is in a name? It is about thinking the différance ${ }^{10}$, being open to the différance and thereby seeking not an absence of violence but an economy of violence that does not strive for equilibrium, as it is not static, as différance is both difference and deferment. This is exactly where the difference lies between Derrida's différance and Žižek's minimal difference or pure difference or the gap orcut. Žižek, equating différance with pure difference, denies the important movement and

(Footnote 9 continues...) Because of this essencing character of language Heidegger spoke of language as the house of being. This metaphor has been taken further specifically within psychoanalysis where one can speak of language as the torturehouse (Žižek 2008:3-4).This violence is a given and it cannot be avoided.

10.'Différance is not only irreducible to any ontological or theological - ontotheological - reappropriation, but as the very opening of the space in which ontotheology - philosophy - produces its system and its history, it includes ontotheology, inscribing it and exceeding it without return' (Derrida 1982:6). force in the thinking of différance (Sands 2008: 531). Žižek argues that pure difference is not between the other and the same, but it is the difference within the same. ${ }^{11}$

The difference or gap remains, but it is empty of force and movement because of Žižek`s interpretation of Derrida. I believe that différance, as Derrida interprets it, is the site of the return of Christ-like faith in modern civilisation and the relation between truth, reason and faith.

\section{Faith, Reason and Truth Beyond violence towards a democratic civilisation still to come}

Truth is never beyond language or metaphor, and thus the truth of truth or the reason of truth is this structural inability of truth (language) as there is always difference, or as Derrida would say, différance, if truth is understood as correspondence and thus the necessity of faith. Truth as coherence is also embedded within a world of meaning in which coherence is established, and this world of meaning is founded on metaphor.

Lacan's discourse of the analyst works with this truth of truth and the question is: What kind of social bond does such a truth (knowledge of difference) create? This knowledge of truth is the result of reason, and yet it reveals the necessity of faith - to believe in a particular metaphor by choosing one metaphor over another without any certainty.

I will conclude with my own faith tradition and possible reasoning strategies within this faith tradition that might help to move beyond the violence of truth and the truth of violence. The 'truths' of Christianity have been and still are, with the rise in Christian fundamentalism, the cause of much violence in the history of the West.

Yet within Christianity, which is my faith, there are other possibilities of interpreting truth that are beyond such blatant violence. These are possibilities that could be useful with regards to opening Western civilisation, which has been greatly influenced by Christianity, for democracies still to come.

In this conclusion, a reflection will be offered of the Christ event and a possible Christian discourse beyond the violence of truth and the truth of violence towards a social bond of welcome offered to democratic civilisations still to come.

\footnotetext{
11.This pure difference Žižek interprets into the relationship between God and Son in the incarnation where the limitation or difference has shifted from without God to within God and thus the idea of a transcendent God is removed and only an immanent materialist interpretation is possible. In his book, The Paralax View, Žižek offers a description of God that can be compared to his interpretation of différance:

Perhaps 'God' is the name for this supreme split between the Absolute and the noumenal Thing and the Absolute as the appearance of itself, for the fact that the two are the same, that the difference between the two is purely formal' (Žižek 2006b:109).

Because of his static view of difference, Žižek can argue that the Christ event has happened and is not something to be expected, but is a past event. He says:

...while Christianity, far from claiming full realization of the promise, accomplishes something far more uncanny: the Messiah is here, he has arrived, the final Event
already took place, and yet the gap (the gap that sustained the messianic promise) remains (Žižek 2006c:232-233)
} 
Christ would not be the agent of such a discourse as a universal absolute truth, just like the analyst is not the agent of the discourse of the analyst. Christ as the 'truth' of this discourse is not the truth of correspondence but truth as a way (cf. Jn 14:6). Augustine spoke of truth as facere veritatum. Truth as action and as the agent of the discourse in the discourse of the analyst is the way of différance (knowledge of both difference and deferment). There are important similarities between this knowledge of différance and the way of Christ (cf. Meylahn 2010; Caputo 2007). The way (truth) that Christ revealed and spoke of is the way of love and more specifically the love of enemies. It is a love that loves the other as other without first reducing the other into something loveable (acceptable) within the same. Besides revealing love, tradition argues that Christ revealed grace. The unconditionality of grace that demands nothing is the way of différance. It does not include the other into the economy of the same, but allows the same to be broken open by that which is beyond the economy of the same. Thus love and grace are the agents (way) of this discourse of the 'truth' of Christ.

Love and grace are also the desires of Christ, the new commandment, the new agency, that he revealed to the world. Thus the agent of this discourse is grace alone revealed in love of the other as other. Yet love and grace are also the desires of humanity. The human needs to be loved - not just loved because one has fulfilled some standard set by the Other, but loved without any fulfilment of criteria, in other words to be loved unconditionally, which is also the desire for grace.

In the Gospel of John, Christ describes himself as the truth, the way and the life (Jn 14). Christ's interpretation of himself as truth is not the truth of a master signifier of absolute correspondence but as a servant signifier signifying a way of living, or we could say knowledge of how to live. What content does Christ give to this knowledge of how to live? It is a way of living which remains open to the other, servant to the other, and thus open to différance as described in Philippians 2:5-11. He commanded those who wanted to follow in this way of life to love, and by loving, they will be identified as those belonging to this way of life. What kind of love was this? Christ answers and says: No greater love can anyone have than to lay down his life for another. I would like to give this laying down of one's life a Derridian interpretation as radical hospitality. Radical hospitality is to open yourself towards the other, to open yourself for différance to such an extent that the self is destroyed or deconstructed. To truly offer hospitality to the other, you allow the other to become host and yourself hostage in your own home (Derrida 2000). This is not just the knowledge of différance, but it is the truth of the knowledge of différance and that is: différance (the other which is not the same), when acknowledged and loved without reducing it to the same, without offering it halfhearted hospitality under the laws of the same (the home), destroys and deconstructs (questions) the self by exposing the self by exposing the truth of the truth of the self.
This love and grace, as agents of the truth, are communicated to the other (society) who are struggling to cope with their half-spoken truths and forgotten metaphors. In the light of love and grace, the self realises that he or she does not need the object of desire to be loved and accepted, thereby love and grace deconstruct the demand (law) of all the objects of desire, signifiers, which have enslaved the self in the master discourse of the market or the other discourses of various truths. This crucifixion (deconstruction) of the demands (laws) that drive the discourses of capitalism and the hysteric releases the self and liberates the self, to recognise themselves in the light of love and grace, and the product of this love and grace is a new identity - a new self-understanding through the knowledge of différance: a dependence on the other.

The product of the Christ discourse is an ' $\mathrm{I}$ ' which is a self that knows (knowledge of différance) that it is debarred from the truth. It has become a debarred 'I' through the agents of love and grace which are revealed through the eyes of the other and which have crucified (deconstructed) the laws (demands) and violence of the various truth discourses that have forgotten their metaphorical origin. This debarred self realises its dependence on the love of the other for its identity as debarred self, no longer as a demand (tell me who I am) but as a product of love. The relation to the other is no longer the relation of the hysteric to the other, but the relation of one who understands themselves in a relationship of love to the other who is debarred as well. Therefore the self discovers themselves as neighbour to the other debarred selves. ${ }^{12}$ Thus as Levinas would say, ethics (responsibility towards the other) becomes the first philosophy (metaphysics, world of meaning) as the self sees him or herself as debarred in the eyes of the other and thus realises their dependence on the love of the debarred other, but simultaneously as one responsible to love the other, and so this Christ discourse creates the social bond of a new community of selves open to receive the other - open for a democracy still to come. It is a discourse that by grace and love deconstructs the demands and the desires of the various discourses and reveals a self that does not have the symptom of being debarred from its truth, but is a debarred (disillusioned) self amongst other debarred selves, co-dependent on love and grace and the hope of a community (civilisation) always still to come.

\section{Acknowledgements Competing interests}

The author declares that he has no financial or personal relationship(s) which may have inappropriately influenced him in writing this paper

\section{References}

Benjamin, W., 1996, 'Critique of Violence', in M. Jennings (ed.), Walter Benjamin: Selected Writings, pp. 236-252, Harvard University Press, Cambridge.

Caputo, J.D., 1982, Heidegger and Aquinas: An Essay on Overcoming Metaphysics, Fordham University Press, New York.

Caputo, J.D., 2007, What would Jesus Deconstruct? The Good News of Post-modernism for the Church, Baker Academic, Grand Rapids.

12.For further reflection on the ethical dependence on the Other in which the self is created as self in responsible love toward the other see (Meylahn 2009) 
Cavanaugh, W.T., 1995, "A fire strong enough to consume the house': the wars of religion and the rise of the state', Modern Theology 11(4), 397-420. http://dx.doi. religion and the rise of the state', Modern
org/10.1111/j.1468-0025.1995.tb00073.x

Derrida, J., 1974, 'White Mythology: Metaphor in the Text of Philosophy', New Literary History 6(1), 5-74. http://dx.doi.org/10.2307/468341

Derrida, J., 1978, Writing and Difference, transl. A. Bass, Routledge, New York.

Derrida, J., 1982, Margins of Philosophy, transl. A. Bass Harvester, Brighton.

Derrida, J., 1997, Of Grammatology, transl. G.C. Spivak, John Hopkins University Press, Baltimore.

Derrida, J., 2000, Of Hospitality: Anne Dufourmantelle invites Jacques Derrida to respond, transl. R Bowlby, Stanford University Press, Stanford.

Fromm, E., 1976, To have or to be? Harper \& Row, New York.

Heidegger, M., 1969, Identity and Difference, transl. J. Stambaugh, Harper \& Row, New York.

Heidegger, M., 1971, Poetry, Language, Thought, transl. A. Hofstadter, Harper \& Row, New York.

Heidegger, M., 2005, 'On the Essence of Truth', in J. Medina \& D. Wood (eds.), Truth: Engagements Across Philosophical Traditions, pp. 244-260, Blackwell, Oxford.

Lacan, J., 2001, 'Radiophonie', in J. Lacan (ed.), Ecrits, pp. 403-448, Seuil, Paris.

Lacan, J., 2006, Book XVII: The other side of psychoanalysis, transl. R. Grigg, W.W. Norton \& Co., New York.

Meylahn, J.-A., 2009, 'Responsibility, God and society: The cry of the Other in the sacred texts as a challenge towards responsible global citizenship', HTS Teologiese Studies/Theological Studies 65(1), Art. \#131, 5 pages. http://dx.doi.org/10.4102/ hts.v65i1.131

Meylahn, J.-A., 2010, 'Holistic Redemptive Pastoral Ministry in the Fragmented Transit Hall of Existence', HTS Teologiese Studies/Theological studies 66(1), 9 pages. http://dx.doi.org/10.4102/hts.v66i1.426
Meylahn, J.-A., 2011, 'Religion and Modernity in a Secular City: A Public Theology of Différance', HTS Teologiese Studies/Theological Studies, 67(3), Art. \#961, 8 pages. $\mathrm{http} / / \mathrm{dx}$.doi.org/10/4102/hts/v67i3.96

Nietzsche, F., 2005, 'On Truth and Lies in a Nonmoral Sense: and other readings', in J.J. Medina, \& D. Wood (eds.), Truth: Engagements Across Philosophical Traditions, pp. 14-25, Blackwell, Oxford.

Sands, D., 2008, 'Thinking through différance: Derrida, Žižek and religious engagement', Textual Practice 22(3), 529-456. http://dx.doi.org/10.1080/09502360802263774

Todorov, T., 2001, 'Totalitarianism: Between Religion and Science', Totalitarian Movements and Political Religion 2(1), 28-42. http://dx.doi.org/10.1080/714005440

Verhaeghe, P., 1995, 'From impossibility to inability: Lacan's theory on the four discourses', The Letter: Lacanian Perspectives on Psychoanalysis 3, Spring, 91-108.

Verhaeghe, P., 1999, Love in a time of loneliness: Three essays on drive and desire, Rebus Press, London.

Wajcman, G., 2003, The hysteric's discourse, viewed 12 June 2009, from http://www. lacan.com/hystericdiscf.htm

Žižek, S., 1997, 'Multiculturalism, or, the Cultural Logic of Multinational Capitalism', New Left Review 1, 34-51.

Žižek, S., 2001, 'Love Without Mercy', The Warwick Journal of Philosophy 11, 171-199.

Žižek, S., 2006a, Jacques Lacan's four discourses, viewed 02 June 2009, from http:// www.lacan.com.zizfour.htm

Žižek, S., 2006b, The Paralax View, MIT Press, Cambridge.

Žižek, S., 2006c, 'A Plea for a Return to Différance', Critical Inquiry 32, Winter, 226-249.

Žižek, S., 2008, 'Language, violence and non-violence', International Journal of Zizek Studies 2(3), 1-12. 